\title{
A társas támogatás és az egészséges életmód összefüggései
}

\author{
Ocsovszky Zsófia ${ }^{1}$ - Rafael Beatrix dr. ${ }^{2}$ - Martos Tamás dr. ${ }^{2}$ \\ Csabai Márta dr. ${ }^{2}$ - Bagyura Zsolt dr. ${ }^{1}$ - Sallay Viola dr. ${ }^{2}$ - Merkely Béla dr. ${ }^{1}$
}

\author{
${ }^{1}$ Semmelweis Egyetem, Városmajori Szív- és Érgyógyászati Klinika, Budapest \\ ${ }^{2}$ Szegedi Tudományegyetem, Bölcsészettudományi Kar, Pszichológiai Intézet, Szeged
}

Bevezetés: A cardiovascularis megbetegedések vezető haláloki tényezőként évente 4 millió halált okoznak Európában. Az életmód mellett 25-40\%-ra becsülik a pszichoszociális tényezők szerepét a betegség létrejöttében. A felnőttkori szociális izoláció a krónikus stressz forrása, és másfélszeres rizikót jelent a betegség kialakulására. A társas támogatás alacsony szintje és a társas izoláció növeli a depresszió, a magas vérnyomás és az elhízás valószínúségét, ezáltal növelve a szív- és érrendszeri megbetegedések előfordulását is.

Célkitűzés: A jelen kutatásban arra voltunk kíváncsiak, hogy hogyan függ össze a vizsgálati személyek egészségmagatartása társas kapcsolataikkal. Továbbá a már korábban validált Multidimenzionális Társas Támogatás Skálát adaptáltuk az egészség területére.

Módszer: Az online kérdőíves adatfelvétel 2018 őszén történt $(\mathrm{n}=507)$. Felvételre került a Társas Támogatás Skála egészségre adaptált változata, a szubjektív egészségi állapot, a szubjektív anyagi helyzet, felvettük a Rövidített Beck Depresszió Kérdőívet, valamint a WHO Rövidített Jóllét Kérdőívet és az Észlelt Stressz Kérdőívet.

Eredmények: A megerősítő faktorelemzés összességében igazolta az eredeti háromfaktoros struktúra meglétét (Cronbach-alfák $=0,945,0,950$ és 0,905$)$. A regressziós modellek szerint az egészséggel kapcsolatban a barátoktól kapott társas támogatás tendenciaszerû pozitív összefüggést mutat az intenzív testmozgással $(\mathrm{B}=0,205$, béta $=0,096$, $\mathrm{p}=0,093)$. Logisztikus regressziós modellben vizsgálva, az egészséggel kapcsolatban kapott társas támogatás nem áll összefüggésben a dohányzással. Csupán az iskolai végzettség mutatkozott szignifikáns tényezőnek $(\mathrm{B}=-1,284$, $\mathrm{OR}=0,277, \mathrm{p}=0,000)$.

Következtetés: A Társas Támogatás Skála egészséges életmódra adaptált változatának pszichometriai mutatói mintánkon megfelelőnek bizonyultak. A társas támogatás összefüggést mutatott a mentális egészség mutatóival (depresszió, stressz-szint, jóllét), valamint tendenciaszerü összefüggést a testmozgással.

Orv Hetil. 2020; 161(4): 129-138.

Kulcsszavak: társas támogatás, szív- és érrendszeri megbetegedés, egészségmagatartás, dohányzás

\section{Correlation of social support and healthy lifestyle}

Introduction: Cardiovascular disease is the leading cause of death accounting for 4 million deaths per year in Europe. Psychosocial factors explain at least $25-40 \%$ of the disease's prevalence beyond the well-known lifestyle factors. Isolation in adulthood is one of the main sources of chronic stress that raises the incidence of the disease. The low level of social support and social isolation are increasing the risk of depression and high blood pressure hence the incidence of cardiovascular diseases.

Aim: Our aim was to observe the correlation between social isolation and health behaviour. Furthermore, we have adapted the earlier validated Multidimensional Social Support Scale to the domain of health.

Method: The data from 507 persons were collected online in 2018. Multidimensional Social Support Scale adapted to health, self-rated health, subjective means, short version of Beck Depression, shortened version of WHO Wellbeing, and Perceived Stress Scales were recorded.

Results: Factor analysis verified the scale construction of the original 3-subscale structure (Cronbach alpha values = $0.945,0.950$ and 0.905$)$. According to the regression models, social support received from friends we have observed to have moderately positive correlation with intensive exercises $(B=0.205$, beta $=0.096, p=0.093)$. Logistic regression model revealed that health-connected social support does not correlate with smoking, only education variable was related with it strongly, statistically significantly $(\mathrm{B}=-1.284, \mathrm{OR}=0.277, \mathrm{p}<0.001)$. 
Conclusion: Multidimensional Social Support Scale has satisfactory stability and consistency to measure health-related social support. Social support showed correlation with the measures of mental health (depression, stress-level, wellbeing), and moderate association with intense exercises.

Keywords: social support, cardiovascular disease, health-behavior, smoking

Ocsovszky Zs, Rafael B, Martos T, Csabai M, Bagyura Zs, Sallay V, Merkely B. [Correlation of social support and healthy lifestyle]. Orv Hetil. 2020; 161(4): 129-138.

(Beérkezett: 2019. augusztus 28.; elfogadva: 2019. szeptember 23.)

\begin{abstract}
Rövidítések
BDI-S = (Beck Depression Inventory, Short version $)$ Rövidített Beck Depresszió Kérdőív; CAD = (coronary artery disease) coronariabetegség; CFI = (comparative fix index $)$ összehasonlító javítási index; CVD = (cardiovascular disease $)$ szív- és érrendszeri megbetegedés; ETT = Egészségügyi Tudományos Tanács; EU = (European Union) Európai Unió; HUNT study $=$ (The Nord-Trøndelag Health Study) a Nord-Trøndelag egészségügyi tanulmány; $\mathrm{HDL}=$ (high-density lipoprotein) magas sưrứségű lipoprotein; ISZB = ischaemiás szívbetegség; MSPSS $=$ (Multidimensional Scale of Perceived Social Support) Multidimenzionális Észlelt Társas Támogatás Kérdőív; NFI $=$ (normed fit index) normált illesztési index; PSS10 = (Perceived Stress Scale-10) Észlelt Stressz Kérdőív, 10-es verzió; RMSEA = (root mean square error of approximation $)$ a közelítés négyzetes középértékének hibája; $S \mathrm{SD}=$ (standard deviáció) a minta szórása; SRH = (self-rated health) szubjektív egészségi állapot; TLI $=$ Tucker-Lewis-index; TUKEB $=$ Tudományos és Kutatásetikai Bizottság; $\mathrm{WHO}=($ World Health Organization) Egészségügyi Világszervezet
\end{abstract}

Habár a cardiovascularis betegségek halálozási mutatói sokat javultak az elmúlt évtizedekben, továbbra is vezető haláloknak számítanak az egész világon mindkét nem esetében. A halálesetek több mint feléért felelősek, így a várható élettartamot jelentős mértékben befolyásolják. A cardiovascularis megbetegedések csaknem fele coronariabetegség (CAD) [1].

Az európai országokban a 2016. évi adatok alapján átlagosan a halálozás 45\%-ának hátterében áll cardiovascularis betegség, ami évente több mint 4 millió halálesetet jelent; ebból 1,8 milliót okoz CAD, illetve 1,4 millió eset 75 éves kor előtt következik be $[2,3]$.

Miközben a népesség átlagéletkora emelkedett, a heveny szívizomelhalásban elhunytak száma hazánkban az 1990. évi 14 ezerről 5700-ra csökkent a 2017-es évre [4]. A visszaesés okai között megemlítendő a hagyományos rizikótényezők csökkenése (a hypertonia, a dyslipidaemia és a cukorbetegség korszerü kezelése miatt), valamint a hatékonyabb és gyorsabb ellátás (az invazív szívkatéterezés elterjedése, a szívkatéteres laborok gyors elérhetősége). Az egészséges életmód jelentőségének széles körü ismerete, az egyre hatékonyabb gyógyszeres terápiák elérhetősége, valamint a dohányzás elleni kampányok is szerepet játszanak a szívinfarktus általi halálo- zás csökkenésében [5]. A javuló eredmények ellenére az ISZB általi halandóság hazánkban még így is több mint kétszerese az EU28 átlagának [6].

A hagyományos rizikótényezők - úgymint magas vérnyomás, cukorbetegség, magas koleszterinszint és elhízás - nem magyarázzák teljes mértékben a szív- és érrendszeri megbetegedések létrejöttét. A betegek, az elérhető szakirodalmi adatok szerint, minimum egy, úgynevezett hagyományos rizikótényezővel rendelkeznek, ugyanakkor például a Budakalász Vizsgálat eredménye alapján elmondható [7], hogy igen gyakori a rizikótényezők halmozott megjelenése, amelyek közül kiemelendő az elhízás és a magas vérnyomás, illetve a dohányzás. Ezek mellett pedig 25-40\%-ra becsülhető a pszichoszociális tényezők szerepe. A szociális és munkahelyi, illetve minden egyéb, tartósan vagy hosszú távon fennálló stresszhelyzet fiziológiai, biológiai változásokat képes előidézni szervezetünkben. Hogy hogyan reagálunk a stresszel teli szituációkra, azt megküzdési, problémamegoldó stratégiáink, valamint társas támaszaink megléte, hozzáférhetősége is befolyásolja [8].

\section{A társas támogatás preventín jelentôsége a cardiovascularis megbetegedések tükrében}

Az ember természeténél fogva társas lény - figyelte meg és jegyezte le immár több mint kétezer éve Arisztotelész. Születésünktől kezdve szükségünk van másokra: csecsemőkortól felnőttkorig az életben maradáshoz, és mint a témában fellelhető, egyre jelentősebb számú szakirodalmi közlemény rámutat, felnőttéletünkben az egészségmagatartáshoz, az egészség fenntartásához, a jólléthez is elengedhetetlen a társas támogatás megléte [9].

A társas kapcsolatok kétféle mechanizmus útján befolyásolhatják pozitívan az egészséget: a stresszcsökkentő és a föhatásmodell alapján. A stresszcsökkentő modell szerint a társas kapcsolatok pszichológiai és materiális forrásokat biztosítanak, így segítik a stresszel való megküzdést. Fontos tényező a segítséget kapó személy számára annak bizonyossága, hogy stresszhelyzetben elérhetők a neki segítséget nyújtó személyek. A hit, hogy a támogatás szükség esetén elérhető, csökkentheti az adott eseményre adott érzelmi és fiziológiai folyamatokat vagy maladaptív viselkedési módokat. A fóhatásmodell azt hangsúlyoz- 
za, hogy a társas kapcsolatok attól függetlenül hatásosak, hogy fennáll-e stresszhelyzet vagy sem. A társas kapcsolatok pozitívan befolyásolhatják a személy egészségmagatartását, például rendszeres testmozgásra, egészséges táplálkozásra és a dohányzás elhagyására ösztönözve őt. A más személyekkel való kapcsolattartás előnyösen befolyásolja az érzelmi szabályozást, növeli a pozitív érzelmek valószínűségét, és csökkenti a negatív érzelmek intenzitását és időtartamát [10-12].

A társas kapcsolatok pozitív hatásával foglalkozó tanulmányok a társas (egészségünket és jóllétünket befolyásoló) hatások két típusát vizsgálták: a társas integrációt és a társas támogatást. A társas integráció a társas kapcsolatok széles körében való részvételre utal, a kapcsolatok számával, az érintkezések gyakoriságával és a kapcsolatok szerkezetével (például nagyság, sűrüség) írható le [13]. A társas támogatás annak megélése, hogy valaki szeret, tisztel és értékel minket, törődik velünk, és része vagyunk egy kölcsönös segítségnyújtáson és kölcsönös kötelezettségeken alapuló társas kapcsolati hálózatnak $[10,14]$.

Bizonyított, hogy az erôs társas kapcsolatokkal rendelkező személyek életben maradási esélye 50\%-kal nagyobb azokhoz képest, akik gyengébb társas kapcsolatokkal rendelkeznek, és az utóbbiaknál a szív- és érrendszeri okból történő elhalálozás is valószínúbb $[15,16]$. HoltLunstad, Smith és Layton metaanalízisükben [17] szintén ismertetik, hogy az erôsebb társas kapcsolatokkal rendelkező egyének túlélési esélye 50\%-kal magasabb magányos vagy rossz kapcsolatokkal rendelkező társaikénál, érdekes módon azonban elsődlegesen nem a házastársi kapcsolat (vagy együttélés) határozta ezt meg, hanem a társadalmi beágyazódás, a szerteágazó és többrétü társas kapcsolatok megléte vagy hiánya.

További, a szakirodalomban elérhető metaanalízis azt is bemutatta, hogy az alacsony társas támogatottság és a társas integráció alacsony szintje hatással van a szív-ér rendszeri megbetegedések létrejöttére, azok progressziójára és a halálozásra is [11], valamint hogy a társas támogatás alacsony szintje növeli a magas vérnyomás kialakulásának és a magas pulzusszámnak a rizikóját [18].

A társas támogatás hiánya vagy nagyon alacsony szintje esetén szociális izolációról beszélünk. Idetartozik, ha valaki nem házas, egyedül él, és elenyésző számú és minőségü kapcsolata van rokonokkal, barátokkal vagy más külső személyekkel. A magány, a társas kapcsolatok hiánya vagy sérülése allosztatikus túltöltöttséget okoz hoszszú távon, többek között gyulladásos folyamatokat indít el szervezetünkben, ami többféle betegség, például cardiovascularis elváltozások kialakulásához vezethet [15, 19-21]. A felnőttkori szociális izoláció és a magány a krónikus stressz közös forrásai, és egészséges (nem szívbeteg) személyeknél másfélszeres rizikót jelentenek az ISZB létrejöttére, valamint a halálozásra [22-24]. A társas támogatás alacsony szintje és a társas izoláció növeli a depresszió, a magas vérnyomás és az elhízás valószínűsé- gét, ezáltal növelve a szív- és érrendszeri megbetegedések előfordulását is [12, 24-28].

A fentieken túl fontos kiemelni azt is, hogy a társas kapcsolatokat elméletileg tágító, azoknak teret adó technológia és globalizáció térnyerése ellenére úgy tûnik, hogy a szociális izoláció mértéke egyre inkább növekszik. Így a társas kapcsolatok társadalmi beágyazódási természetének és egészségre gyakorolt hatásainak vizsgálata kiemelt területét kell, hogy képezze a jövőbeli kutatásoknak. A jelen kutatásban arra voltunk kíváncsiak, hogy hogyan függ össze a vizsgálati személyek egészségmagatartása társas kapcsolataikkal. Tekintettel arra, hogy az egészségre, egészségmagatartásra vonatkozóan mérőeszköz magyar nyelven nem található, a már korábban validált MSPSS-t adaptáltuk az egészség területére. A teljes tesztbattéria-felsorolást ld. az Eszközök cím alatt.

\section{Módszer}

\section{Minta és eljárás}

Az adatfelvétel kényelmi mintavételezéssel történt 2018 őszén a Nemzeti Szívprogram keretében a Budakalász Vizsgálat [7] előkészítéseként, a tesztbattéria validálása során. A kutatási kérdőívet online kitöltéssel, a Carsten Schmitz által fejlesztett LimeSurvey platformon keresztül vettük fel, mely a Szegedi Tudományegyetem védett szerverén üzemelt. A kutatáshoz előzetesen megkaptuk az ETT TUKEB etikai engedélyét (a TUKEB-engedély száma: 53056-2/2018/EKU).

Mivel a kutatás alapvető célja a szív- és érrendszeri megbetegedésekkel kapcsolatos attitűdök és ismeretek felmérése volt a Nemzeti Szívprogram keretében, a kutatásban való részvétel kritériumaként a 35. életév betöltését határoztuk meg, és ezt jeleztük a lehetséges kitöltők felé is. Azokat a 35 évnél fiatalabbakat, akik mégis kitöltötték a kérdőívet, kizártuk a végleges elemzésből. A mintavétel során egyéb szempontból a lehetséges legnagyobb heterogenitásra törekedtünk. A kitöltés megkezdése előtt a kutatásban részt venni szándékozók részletes tájékoztatást kaptak, miszerint a vizsgálatban való részvételük teljesen önkéntes és anonim. A kitöltők a részvételt informált beleegyezés megadása után kezdhették meg.

A vizsgálatban összesen 559 kitöltő vett részt, közülük a jelen elemzés számára 507 fó adatait tudtuk felhasználni, az életkori szürés és a jelentős kitöltési hiányok miatt. A résztvevők 28,0\%-a, 142 személy férfi, 70,8\%, 359 személy nő volt; hatan nem adták meg a nemüket. Az életkor tekintetében a teljes elemzett (507 fös) mintára vonatkozóan van adatunk: a kitöltők átlagéletkora 50,01 év volt (szórás: 8,14 év), azaz a szív- és érrendszeri kockázatok vizsgálata szempontjából érvényes mintát sikerült gyüjteni. A minta 58,8\%-a felsőfokú, 25,0\%-a középfokú, 16,2\%-a pedig alapfokú végzettséggel rendelkezett (298, 127 és 82 fó a fenti sorrendben). A családi állapot szempontjából 140 fó $(27,6 \%)$ egyedül, míg 365 fó 
(72,0\%) házastárssal, élettárssal vagy más családtaggal élt együtt, két személy pedig, aki részt vett a vizsgálatban, nem adott választ.

Feltártuk továbbá a szív- és érrendszeri betegségek meglétét is a kitöltőknél. Az egészségi állapot részletes, önbevalláson alapuló kérdéssorára adott válaszokban összesen 183 fó $(36,1 \%)$ jelezte, hogy az alábbi tünetek közül egy vagy több fennáll nála: szabálytalan szívverés, szívritmuszavar, pitvarfibrilláció, bármely egyéb szívbetegség, hypertonia. A válaszadók megadták továbbá, hogy dohányoznak-e jelenleg (376 fö, azaz 74,2\% nem, 129 fö, vagyis $25,4 \%$ igen, 2 fö pedig nem válaszolt).

\section{Eszközök}

Multidimenzionális Társas Támogatás Skála: Az eredeti MSPSS rövid, önjellemzős, önkitöltős kérdőív, melyet az észlelt társas támogatás szubjektív mérésére fejlesztettek ki. Az eredeti kérdőív 12 tételt tartalmaz, melyeket 7 pontos Likert-skálán kell pontoznia a kitöltőnek a 'nagyon nem értek egyet' (1) megállapítástól a 'nagyon egyetértek' megállapításig (7) [29, 30]. A kérdőív 3 alskálája: család, barátok és jelentős mások támogatása - minden alskálában négy tétel található [29] (példaitemek az egyes alskálákból az alábbi táblázatban találhatók).

Példaitemek az egyes alskálákban

\begin{tabular}{ll}
\hline Család & $\begin{array}{l}\text { A családomra mindig számíthatok az } \\
\text { egészségem megörzésével kapcsolatban. }\end{array}$ \\
\hline Barátok & $\begin{array}{l}\text { Vannak barátaim, akikkel megoszthatom } \\
\text { az örömömet és a bánatomat az egészsé- } \\
\text { gemmel kapcsolatban. }\end{array}$ \\
\hline Jelentős mások & $\begin{array}{l}\text { Van legalább egy olyan fontos személy az } \\
\text { életemben, aki törődik az egészségemmel } \\
\text { kapcsolatos érzéseimmel. }\end{array}$ \\
\hline
\end{tabular}

A 'jelentős mások’ kifejezés a kitöltő számára fontos, speciális személyre (személyekre) vonatkozik (ez lehet például barát, barátnő, tanár, tanácsadó) [31]. Az egyes skálákon elért pontszám az abban található tételek összeadásából származik. A kérdőívben fordított tétel nem található, így minél magasabb pontot ér el a személy egy adott faktoron, annál magasabb az észlelt társas támogatás mértéke. A Zimet és társai által kifejlesztett kérdőív pszichometriai mutatói jó belső megbízhatóságot mutattak. A magyar nyelvü adaptációt Papp-Zipernovszky Orsolya, Kékesi Márk Zoltán, Jámbori Szilvia végezték 2017-ben [32]. A teljes, magyar nyelvü kérdőív Cronbach- $\alpha$-mutatója 0,907, és az egyes faktorok mindegyike igen erős konzisztenciát mutatott a validálás során: család $(0,91)$; barátok $(0,932)$; jelentős mások (0,871). A kérdőív 1073 felnőtt (átlagéletkor: 41,09 év [SD = 10,915], a kitöltők 72,9\%-a nő, 27,1\%-a férfi) bevonásával került validálásra.
Szubjektiv egészségi állapot (SRH): Egy kérdés mérte a válaszadónak a saját egészségi állapotára vonatkozó értékelését: „Összességében milyennek értékeli az egészségi állapotát?" Az öt válaszlehetőség a nagyon rossztól a kiválóig terjedt.

Szubjektív anyagi helyzet: A válaszadónak a saját anyagi helyzetére vonatkozó értékelését tízfokú skálán mértük, melynek végpontjai: 1 = nagyon rossz, 10 = nagyon jó.

Röviditett Beck Depresszió Kérdőin (BDI-S): Az eredeti, 21 tételes kérdőív kilenc tételét tartalmazza, és nagy mértékben korrelál vele $(\mathrm{r}=0,92, \mathrm{p}<0,001)$. A leggyakrabban használt kérdőív a depressziós tünetegyüttes súlyosságának megállapítására és a hangulati állapot követésére. Diagnosztikus célzattal nem használható. A válaszadás négyfokozatú skálán történik: 0 (nem jellemző) - 3 (teljesen jellemző) $[33,34]$. A skála belső megbízhatósága a mintánkban kiváló volt (alfa =0,835).

WHO Röviditett Jóllét Kérdőiv: A WHO-kérdőív az egyik leggyakrabban használt, a jóllét önértékelésén alapuló mérőeszköz. A kezdeti kérdőív 28 tételes rövidített, 5 tételből álló változata a személyeknek a megelőző két hétben átélt általános közérzetét vizsgálja. A válaszadás négyfokozatú skálán történik: 0 (egyáltalán nem jellemző) - 3 (teljesen jellemző). A Hungarostudy 2002-ben alkalmazták először a kérdőívet. Susánszky és $m t s a i$ végezték el a hazai validálását, mely szerint az átlagos érték 7,8 (szórás: 3,8) volt. Az ennél alacsonyabb pontszám a jóllét alacsonyabb szintjét jelzi [35]. A skála belső megbízhatósága a mintánkban kiváló volt (alfa = 0,856).

Észlelt Stressz Kérdőin, 10-es verzió (PSS10): A kérdőív segítségével a vizsgálati személy életkörülményeivel, gondolkodásmódjával, szociális környezetével, valamint az életmódjában bekövetkező változásaival összefüggő stressz-szintjének változásait mérhetjük. A kérdőív a kitöltő stresszészlelését jellemzi, azaz hogy szubjektíven mennyi stresszhelyzetet élt át, ennek következtében pedig mennyire tartja mindennapjait kiszámíthatatlannak, befolyásolhatatlannak. Tekintve, hogy nem specifikus helyzetekre kérdezünk rá, a személy által átélt napi események érdemben nem befolyásolják az adott válaszokat, vagyis a kérdőív összpontszámai, illetve annak változásai jól mutatják a személy stressz-szintjében bekövetkező változásokat. A kitöltők 5 fokú Likert-skálán 1-5-ig ( 1 - soha, 2 - szinte soha, 3 - néha, 4 - elég gyakran, 5 - nagyon gyakran) terjedően jelölik, hogy az adott állítás a megelőző egy hónapban mennyire jellemezte őket. A kérdőív 4 fordított tételt tartalmaz, amelyek esetében az adott pontszámok felcserélődnek. Az egyes tételeknél elért magasabb pontszámok a stresszhelyzetek nagyobb gyakoriságát jelzik, míg a fordított itemek esetében a stresszhelyzetekkel való sikeresebb megküzdést mérhetjük. A kérdőív egyes tételeire adott válaszok összpontszáma az észlelt stressz globális mutatója [36]. A skála belső megbízhatósága a mintánkban kiváló volt $($ alfa $=0,805)$. 


\section{Eredmények}

\section{Az egészség területére adaptált}

Multidimenzionális Észlelt Társas Támogatás

Kérdōin strukturális elemzése és megbizhatósága

Papp-Zipernovszky és mtsai [32] igazolták az eredeti kérdóív (MSPSS) magyar változatának háromfaktoros szerkezetét. Annak érdekében, hogy ugyanezt megvizsgáljuk az egészséggel kapcsolatos támogatásra adaptált kérdőívünk esetében is, a kérdőív struktúrájának ellenőrzésére a jelen vizsgálat adatain először megerősítő faktorelemzést végeztünk. Három egymással korreláló latens faktorral határoztuk meg a modellt, melyek a családtagoktól, a barátoktól és általában az emberektől az egészséggel kapcsolatban kapott támogatást mérő négy-négy tételt reprezentálták.

A megerősítő faktorelemzés összességében igazolta az eredeti háromfaktoros struktúra meglétét: a modell illeszkedési mutatói megfelelőek voltak (khi-négyzet (47) $=239,6 ; \mathrm{NFI}=0,966 ; \mathrm{TLI}=0,962, \mathrm{CFI}=0,973$; RMSEA $=0,089)$. Az egyes tételek és a latens faktorok közötti együtthatók minden változó esetében legalább 0,81 értékűek voltak. Megjegyezzük, hogy a latens faktorok közötti korrelációs együtthatók értéke is viszonylag magas volt, 0,62-tól 0,87-ig terjedt (ez utóbbi a családi és az emberek részéról általában kapott támogatás faktorai között), ami arra utal, hogy az egyes támogatási módok megtapasztalása jelentős mértékben együtt jár. (A részletes elemzést kérésre rendelkezésre bocsátjuk.)

A három alskála megbízhatóságát a Cronbach-féle alfa-együttható értékével becsültük. Mindhárom alskála - a családtagoktól, a barátoktól és általában az emberektől az egészséggel kapcsolatban kapott támogatás - esetében megfelelően magas értéket kaptunk (alfa = 0,945, 0,950 és 0,905 , a fenti sorrendben).

\section{Leiró statisztika és alapvető összefüggések}

Az 1. táblázatban bemutatjuk a három alskála kétváltozós összefüggéseit néhány szociodemográfiai és egészségjellemzővel, valamint a mentális egészség jellemzőivel (depresszivitás, észlelt stressz és jóllét). A társas támogatás szubjektív észlelése szempontjából a legfontosabb a családtól és a barátoktól kapott támogatás; az életkor, nem szignifikáns mértékben ugyan, de gyengén és negatívan korrelál, vagyis az életkor előrehaladtával az észlelt támogatás szintje valamelyest csökken. Ugyanez a negatív tendencia figyelhető meg a depresszivitás és az észlelt stressz tekintetében: minél magasabb az elért pontszám, annál alacsonyabb az észlelt támogatás szintje. Az intenzív testmozgás $(\rho=0,097, p<0,05)$, a szubjektív egészségi állapot $(p=0,270, p<0,001)$ és a jóllét $(r=0,322$, $\mathrm{p}<0,001$ ) azonban pozitív együttjárást mutat (erősebbet a barátok támogatásával), vagyis a magasabb észlelt támogatás esetén több testmozgásról számolnak be a válaszadók.
1. táblázat Az egészséggel kapcsolatos társas támogatás kétváltozós össze függései

\begin{tabular}{llll}
\hline \multicolumn{4}{l}{ Társas támogatás (egészség) } \\
\hline Család & Barátok & Általában \\
\hline
\end{tabular}

Korrelációs összefüggések

Társas támogatás -

család

Társas támogatás - $\quad 0,591 * * *$

barátok

Társas támogatás - $\quad 0,816^{* * *} \quad 0,670 * * *$

általában

Életkor

SRH

Intenzív testmozgás

$0,244^{* * *} \quad 0,272$ *** 0,218 ***

BDI-S

$0,135^{* *} \quad 0,097$ * 0,084

PSS10

$-0,343^{* * *}-0,316^{* *}-0,297$ ***

PSS10

$-0,347^{* * *}-0,306^{* * *}-0,303$ ***

WHO Jóllét

0,372 ** $0,322 * * *$

$0,311 * * *$

\begin{tabular}{llll}
\hline A csoportok összehasonlitása & & \\
Nem & & & \\
Férfiak m (SD) & $4,39(0,86)$ & $3,96(0,99)$ & $4,42(0,75)$ \\
Nók m (SD) & $4,24(0,91)$ & $4,05(0,99)$ & $4,33(0,83)$ \\
$\mathrm{t}$ & 1,69 & $-0,88$ & 1,12 \\
\hline Iskolai végzettség & & & \\
Alapfok m (SD) & $4,45(0,79)$ & $4,05(0,96)$ & $4,44(0,75)$ \\
Középfok m (SD) & $4,20(0,93)$ & $4,02(1,00)$ & $4,31(0,77)$ \\
Felsófok m (SD) & $4,28(0,90)$ & $4,03(1,00)$ & $4,36(0,84)$ \\
F & 2,07 & 0,02 & 0,67 \\
\hline Társas status & & & \\
Egyedül él m (SD) & $4,04(1)$ & $3,93(1)$ & $4,2(0,89)$ \\
Családban él m (SD) & $4,38(0,83)$ & $4,06(0,99)$ & $4,42(0,77)$ \\
t & $-3,87 * * *$ & $-1,34$ & $-2,72 * *$ \\
\hline Dohányzás & & & \\
Nem dohányzik m & $4,31(0,87)$ & $4,02(0,98)$ & $4,38(0,78)$ \\
(SD) & & & \\
Dohányzik m (SD) & $4,23(0,95)$ & $4,05(1,02)$ & $4,29(0,89)$ \\
t & 0,91 & $-0,3$ & 15 \\
\hline
\end{tabular}

Megjegyzések: SRH = szubjektív egészségi állapot. Az SRH és az intenzív testmozgás esetében Spearman-féle rho, egyéb korrelációs együtthatók Pearson-féle $\mathrm{r} .{ }^{*} \mathrm{p}<0,05,{ }^{*} \mathrm{p}<0,01,{ }^{* *}{ }^{*} \mathrm{p}<0,001$; a nem jelölt statisztikai értékek esetén $\mathrm{p}>0,05$

BDI-S = Rövidített Beck Depresszió Kérdőív; PSS10 = Észlelt Stressz Kérdőív, 10-es verzió; $\mathrm{SD}=$ a minta szórása; $\mathrm{WHO}=$ Egészségügyi Világszervezet

A nemek és az iskolai végzettség vonatkozásában nem mutatkozik szignifikáns eltérés a társas támogatás mértékében; a társas status tekintetében a családban élők nagyobb támogatásról számolnak be a család $(\mathrm{t}=-3,87$, $\mathrm{p}<0,001)$ és egyéb személyek irányából is $(\mathrm{t}=-2,72$, $\mathrm{p}<0,01)$. A dohányzók társas támogatása sem különbözik szignifikánsan a nem dohányzókétól. 
Az intenzív testmozgás mennyiségének összefüggései regressziós modellben

\begin{tabular}{lccl}
\hline & \multicolumn{3}{c}{ Intenzív testmozgás } \\
\hline & $\mathrm{B}$ & béta & $\mathrm{p}$ \\
\hline Nem & $-0,52$ & $-0,113$ & 0,015 \\
Életkor & 0,024 & 0,092 & 0,048 \\
Isk. dummy 1 & $-0,869$ & $-0,181$ & 0,005 \\
Isk. dummy 2 & $-1,707$ & $-0,402$ & 0 \\
Együtt él / házas (vs. egyedül) & 0,05 & 0,011 & 0,821 \\
CVD van (vs. nincs) & $-0,374$ & $-0,088$ & 0,058 \\
Társas támogatás - család & 0,033 & 0,014 & 0,81 \\
Társas támogatás - barátok & 0,205 & 0,096 & 0,093 \\
& $R^{2}$ & 0,108 & \\
& $\mathrm{~F}$ & 4,309 & \\
& $\mathrm{p}$ &, $000 \mathrm{~d}$ & \\
\hline
\end{tabular}

CVD = szív- és érrendszeri megbetegedés

\section{A társas támogatás, az intenzív testmozgás és a dohányzás összefüggései}

Többszörös logisztikus és lineáris regressziós modellekkel vizsgáltuk, hogy az egészséggel kapcsolatos társas támogatás milyen mértékben jelzi elóre az intenzív testmozgás mennyiségét, illetve a mentális egészség mutatóit. A modellekben a családi és az általános támogatás közötti magas korreláció és az ebből fakadó magas multikollinearitás miatt a baráti támogatás mellett csak a családi támogatást szerepeltettük, hogy a modellek instabilitását elkerüljük. A modellekbe bevezetésre került a nem, az életkor, az iskolai végzettség (ez utóbbit kétér- tékú, ún. 'dummy' változókká átkódolva, az alapfokú végzettséget referenciaként tekintve), a családi állapot, valamint a szív- és érrendszeri betegségek önbevalláson alapuló statusa, a társas támogatás két változója (2. táblázat). A regressziós modellek eredménye alapján az egészséggel kapcsolatban a barátoktól kapott társas támogatás tendenciaszerúen pozitívan összefügg az intenzív testmozgás mennyiségével $(\mathrm{B}=0,205$, béta $=0,096$, $\mathrm{p}=0,093)-$ kontrollálva a válaszadó nemére, életkorára, iskolai végzettségére, családi állapotára és (önbevalláson alapuló) CVD-statusára.

Egy további elemzésben ugyanezzel az elemzési logikával vizsgáltuk azt is, hogy a társas támogatás hogyan függ össze a dohányzással (3. táblázat). Az eredmények alapján elmondható, hogy sem a családtagoktól, sem a barátoktól az egészséggel kapcsolatban kapott társas támogatás nem áll összefüggésben a dohányzással (kontrollálva a válaszadó nemére, életkorára, iskolai végzettségére, családi állapotára és [önbevalláson alapuló] CVD-statusára). Kizárólag az iskolai végzettség korrelált szignifikánsan a dohányzással (a magasabb végzettségüek kevésbé valószínú, hogy dohányoznak) $(\mathrm{B}=-1,284$, $\mathrm{OR}=0,277, \mathrm{p}=0,000)$.

A társas támogatás kapcsolatát elemezve a mentális egészség mutatóival (4. táblázat) a következő eredményeket kaptuk: Az egészséggel kapcsolatban a családtagoktól (depresszió: $\mathrm{B}=-0,943$, béta $=-0,219, \mathrm{p}=$ 0,000 ; észlelt stressz: $\mathrm{B}=-0,172$, béta $=-0,213, \mathrm{p}=$ $0,000)$ és külön a barátoktól kapott társas támogatás (depresszió: $\mathrm{B}=-0,599$, béta $=-0,155, \mathrm{p}=0,005$; észlelt stressz: $\mathrm{B}=-0,109$, béta $=-0,150, \mathrm{p}=0,007)$ is negatív együttjárást mutat a depresszivitással és az észlelt stressz-szinttel (kontrollálva a válaszadó nemére, életkorára, iskolai végzettségére, családi állapotára és [önbeval-

3. táblázat |A dohányzás összefüggései logisztikus regressziós modellben

\begin{tabular}{|c|c|c|c|c|c|}
\hline & \multicolumn{5}{|c|}{ Dohányzás } \\
\hline & B & OR & $95 \% \mathrm{CI}$ & & $\mathrm{p}$ \\
\hline Nem & 0,118 & 1,125 & 0,672 & 1,883 & 0,653 \\
\hline Életkor & 0,001 & 1,001 & 0,973 & 1,031 & 0,922 \\
\hline Isk. dummy 1 & $-0,559$ & 0,572 & 0,3 & 1,088 & 0,089 \\
\hline Isk. dummy 2 & $-1,284$ & 0,277 & 0,153 & 0,5 & 0 \\
\hline Együtt él / házas (vs. egyedül) & $-0,31$ & 0,733 & 0,44 & 1,221 & 0,233 \\
\hline CVD van (vs. nincs) & $-0,321$ & 0,725 & 0,45 & 1,167 & 0,186 \\
\hline Társas támogatás - család & $-0,163$ & 0,85 & 0,609 & 1,186 & 0,338 \\
\hline \multirow[t]{6}{*}{ Társas támogatás - barátok } & 0,243 & 1,275 & 0,936 & 1,736 & 0,123 \\
\hline & & $R^{2}$ & & & \\
\hline & & Cox-Snell & 0,057 & & \\
\hline & & Nagelkerke & 0,085 & & \\
\hline & & $\mathrm{Khi}^{2}$ & 26,229 & & \\
\hline & & $\mathrm{p}$ & 0,001 & & \\
\hline
\end{tabular}

CVD = szív- és érrendszeri megbetegedés 
4. táblázat |A mentális egészség mutatóinak összefüggései regressziós modellben

\begin{tabular}{|c|c|c|c|c|c|c|c|c|c|}
\hline & \multicolumn{3}{|c|}{ BDI } & \multicolumn{3}{|c|}{ Észlelt stressz } & \multicolumn{3}{|c|}{ WHO Jóllét } \\
\hline & B & béta & $\mathrm{p}$ & B & béta & $\mathrm{p}$ & B & béta & $\mathrm{p}$ \\
\hline Nem & 0,6 & 0,072 & 0,104 & 0,085 & 0,054 & 0,228 & $-0,233$ & $-0,038$ & 0,406 \\
\hline Életkor & $-0,075$ & $-0,16$ & 0 & $-0,008$ & $-0,088$ & 0,052 & 0,037 & 0,106 & 0,02 \\
\hline Isk. dummy 1 & $-1,726$ & $-0,198$ & 0,001 & $-0,383$ & $-0,235$ & 0 & 1,073 & 0,166 & 0,008 \\
\hline Isk. dummy 2 & $-1,101$ & $-0,143$ & 0,018 & $-0,25$ & $-0,173$ & 0,005 & 0,49 & 0,086 & 0,169 \\
\hline Együtt él/házas (vs. egyedül) & $-0,17$ & $-0,02$ & 0,656 & $-0,051$ & $-0,031$ & 0,486 & 0,119 & 0,019 & 0,68 \\
\hline CVD van (vs. nincs) & 1,703 & 0,221 & 0 & 0,25 & 0,173 & 0 & $-1,088$ & $-0,191$ & 0 \\
\hline Társas támogatás - család & $-0,943$ & $-0,219$ & 0 & $-0,172$ & $-0,213$ & 0 & 0,771 & 0,236 & 0 \\
\hline Társas támogatás - barátok & $-0,599$ & $-0,155$ & 0,005 & $-0,109$ & $-0,15$ & 0,007 & 0,438 & 0,152 & 0,006 \\
\hline$R^{2}$ & 0,212 & & & 0,18 & & & 0,191 & & \\
\hline $\mathrm{F}$ & 14,362 & & & 11,737 & & & 12,34 & & \\
\hline $\mathrm{p}$ & $0,000 \mathrm{c}$ & & & $0,000 \mathrm{c}$ & & & $0,000 \mathrm{c}$ & & \\
\hline
\end{tabular}

BDI = Beck Depresszió Kérdőív; CVD = szív- és érrendszeri megbetegedés; WHO = Egészségügyi Világszervezet

láson alapuló] CVD-statusára). Összegezve tehát, mind a családtagoktól, mind a barátoktól kapott társas támogatás szignifikáns mértékben negatívan korrelál a személy depresszió-, illetve észlelt stressz-szintjével.

A jóllét esetében pedig az egészséggel kapcsolatban a családtagoktól $(\mathrm{B}=0,771$, béta $=0,236, \mathrm{p}=0,000)$ és külön a barátoktól $(\mathrm{B}=0,438$, béta $=0,152, \mathrm{p}=0,006)$ kapott társas támogatás is pozitív együttjárást mutatott: a társas támogatás nagyobb mértéke a jóllét magasabb szintjével járt együtt.

\section{Megbeszélés}

Egyre több a szakirodalmi bizonyíték arra nézve, hogy a társas kapcsolatok összefüggnek a cardiovascularis betegségek kialakulásával, progressziójával és a mortalitással. Bár a szakirodalmi adatok vegyesek, az adatok többsége mégis arra utal, hogy az alacsony társas támogatottság (típustól függetlenül) 1,5-2,1-es kockázatot jelent mind az egészséges populáció, mind a koszorúér-betegségben szenvedő betegek esetében $[9,22,27]$. Az alacsony szintû társas támogatás az egészségkárosító magatartások, negatív pszichológiai folyamatok és direkt úton, fiziológiai mechanizmusok által fejtik ki kedvezőtlen hatásaikat [11]. Ugyanakkor fontos megjegyezni, hogy a kutatások során a társas támogatás konstruktumát sokféleképpen definiálják és mérik [11].

Kutatásunkban az MSPSS-t adaptáltuk az egészség területére, hogy megmérjük az észlelt társas támogatás szubjektív mértékét és hatását az egészségmagatartásra. A család, a barátok és jelentős mások (például barát, barátnő) egészséggel kapcsolatos támogatásának hatását elemeztük a vizsgálati személyek (szív- és érrendszeri betegségben szenvedők, illetve nem szenvedők) egészségmagtartása (dohányzás és testmozgás), depresszív hangulata, észlelt stressz-szintje és jólléte szempontjából.
Regressziós modelljeinkben minden esetben kontrollváltozóként szerepelt a vizsgálati személyek neme, életkora, iskolai végzettsége, családi állapota és aktuális kardiológiai statusa (van-e diagnosztizált szív- és érrendszeri megbetegedése vagy sem?).

Vizsgálati eredményeink szerint az egészséggel kapcsolatban a barátoktól kapott társas támogatás tendenciaszerüen, pozitívan jár együtt a testmozgás mennyiségével, azonban az általunk vizsgált más egészségmagatartások és a dohányzás esetében nem volt szignifikáns a kapcsolat. Kizárólag az iskolai végzettséggel mutatott pozitív összefüggést a dohányzás: az alacsonyabb iskolai végzettségúek körében nagyobb az előfordulása a dohányzásnak. A fennálló kardiológiai status nem mutatott semmilyen irányban szignifikáns együttjárást a személyek egészségmagatartásával. Összefoglalva az eredményeket: a barátoktól kapott társas támogatás statisztikailag szignifikáns mértékben pozitívan jár együtt a rendszeres intenzív testmozgással, mely protektív hatással bírhat a szív- és érrendszeri megbetegedésekkel szemben. Ez alátámasztja Fisher Aggarwal és mtsai eredményeit, akik arról számolnak be kutatásukban, hogy a nagyobb társas támogatás (instrumentális és érzelmi) pozitívan korrelál a hetente fizikai aktivitással töltött idővel. Multidimenzionálisan értelmezve az eredményeket: a magasabb mértékű érzelmi társas támogatás magasabb HDL-koleszterin-szinttel és magasabb mértékü testmozgással járt együtt, amely változók nagy mértékben hozzájárulhatnak a szív- és érrendszeri rizikó csökkenéséhez [37].

Piwońszki és mtsai [38] kutatásukat lengyel populáción folytatták le, 7379 fös mintán. A magasabb társas támogatottság összefüggéseit vizsgálták az egészségesebb életmóddal, a magasabb szintû egészségmagatartással, ezeken keresztül pedig az alacsonyabb cardiovascularis rizikóval. Eredményeik szerint a férfiaknál az alacsonyabb társas támogatottság a koszorúér-betegséggel 
közvetlenül nem mutatott összefüggést, de rosszabb egészségmagatartással, dohányzással, elhízással, magas koleszterinszinttel és depresszióval járt együtt, míg a nők körében a dohányzáson, elhízáson, magas koleszterinszinten és depresszión kívül a koszorúér-betegséggel is összefüggést mutatott. Összességében az alacsonyabb társas támogatást élvezők egészségtelenebb életvitelt folytattak a magasabb támogatással bíróknál. Valószínú azonban, hogy a társas kapcsolatoknak nem csak pozitív hatása van az egészségmagatartásra, gondoljunk itt a dohányzó, illetve a testmozgás terén inaktív családtag vagy barát esetlegesen negatív befolyásoló hatására [16].

További vizsgálati eredményeink szerint az egészséggel kapcsolatban a családtagoktól és a barátoktól kapott társas támogatás negatívan függ össze a depresszió szintjével, ez összecseng korábbi kutatási adatokkal [39, 40, 41], valamint eredményeink szerint pozitív együttjárást mutat az észlelt stressz-szinttel és a jólléttel. A családtagok és barátok által nyújtott társas támogatás tehát fordítottan függ össze a depresszív tünetek és a magasabb stressz-szint kialakulásával és pozitívan a személy magasabb szintü jóllétével. Tekintve, hogy mindezek a környezeti hatások pedig összefüggést mutatnak a szív- és érrendszeri betegségek kialakulásával, ha a betegség kialakulását vizsgáljuk, a társas támogatás szerepe, úgy tünik, nem kihagyható faktor.

Rutledge és mtsai [26] is alacsonyabb depresszióértéket találtak vizsgálatukban a magasabb társas kapcsolati rendszerrel rendelkező nők között, mint a társas kapcsolatok alacsonyabb szintjével rendelkezőknél. Gafarov és $m$ tsai [42] vizsgálati eredményei szerint az alacsony társas támogatással rendelkező nők körében magasabb az észlelt stressz-szint a munka és a társas kapcsolatok terén. Compare és mtsai áttekintő tanulmánya szerint [43] öszszetett kapcsolat mutatkozik a társas támogatás, a depresszió és a szívbetegségek között. Az alacsony társas támogatás és a depresszió egymástól függetlenül is rizikótényezők a szívbetegségek kialakulásának és prognózisának vonatkozásában, azonban az alacsony társas támogatás következményeként is létrejöhet depresszió, illetve súlyosbodhatnak a már fennálló depressziós tünetek.

A HUNT-tanulmányban [44] több mint 40 000, 20 és 89 év közötti (nem szívbeteg) férfit és nőt vizsgáltak. Eredményeik szerint az életkor előrehaladtával az egészség szempontjából, beleértve a depressziót, a nőknél egyre nagyobb szerepe van az észlelt társas támogatás érzelmi típusának, míg a férfiak számára a „kézzelfogható, gyakorlati” támogatás valószínű elérhetősége a legfontosabb.

\section{Következtetés}

Vizsgálatunk során megállapítottuk, hogy a korábban magyar nyelvre fordított és validált Multidimenzionális Észlelt Társas Támogatás Skála pszichometriailag alkalmas arra, hogy az egészség területére alkalmazva felmér- hessük, hogy a társas támogatás hogyan függ össze az egészségmagatartással. Mindez azért fontos, mert korábbi hazai szakirodalmi és nemzetközi eredmények alapján is feltételeztük, hogy a szív- és érrendszeri megbetegedések hátterében meghúzódó életmódbeli és lelki tényezők összefüggnek az egyén szociális integrációjának mértékével. A jelen kutatás rávilágított, hogy az észlelt társas támogatás szintje pozitív együttjárást mutat az intenzív testmozgással, illetve az észlelt stressz-szinttel és a jólléttel, és negatívan korrelál a depresszív hangulattal. Mindezen tényezők nagy mértékben összefüggnek a szív- és érrendszeri betegségek kialakulásával, így összefoglalva elmondható, hogy a társas támogatás hatással lehet ilyen betegség kialakulására. A tanulmány erőssége, hogy egy erôs konzisztenciájú mérőeszközt alkalmassá tesz egy új terület mérésére, így kitágítva a társas támogatás szerepének vizsgálatát egy speciális tartományra, az egészségre. Továbbá ennek kipróbálása során rámutat olyan összefüggésekre, amelyek a cardiovascularis megbetegedések multifaktoriális vizsgálata során fontos szempontra világítanak rá, és teszi mindezt egy statisztikailag jól értelmezhető mintanagyságon ( $n=507)$. Gyengesége, hogy a tanulmány egy kényelmi mintát vizsgál, melyben a résztvevők nagy többsége $(70,8 \%)$ nő, így a nemek aránya eltért a populációban tapasztalhatótól, az eredmények általánosíthatósága ezért korlátozott.

Anyagi támogatás: A jelen tanulmány megjelenését a Nemzeti Kutatási, Fejlesztési és Innovációs Hivatal támogatta (NKFIA; NVKP-16-1-2016-0017 Nemzeti Szívprogram).

Szerzői munkamegosztás: O. Zs.: A kutatási terv kidolgozása, irodalomkutatás, a közlemény megírása. R. B.: A kutatási terv kidolgozása, irodalomkutatás, részvétel a közlemény megírásában. M. T.: A kutatási téma felvetése, a kérdőív kidolgozása, statisztikai elemzések elvégzése, az adaptált mérőeszköz pszichometriai mutatóinak elkészítése. Cs. M.: A kutatási téma felvetése, kidolgozása, a kutatás szervezése, a kézirat szövegének ellenőrzése. B. Zs.: Irodalomkutatás, a statisztikai elemzések ellenőrzése, a kézirat szövegének áttekintése. S. V.: A kutatási terv kidolgozása, a kutatás megszervezése és lebonyolítása, a kérdőív összeállítása. M. B.: A kutatás felügyelete, a kézirat ellenőrzése és jóváhagyása. A cikk végleges változatát valamennyi szerző elolvasta és jóváhagyta.

Érdekeltségek: A szerzőknek nincsenek a cikk témájával kapcsolatos érdekeltségeik.

\section{Köszönetnyilvánítás}

Köszönjük a SZTE pszichológia szakos hallgatóinak - Ádok Hajnalkának, Balázs Orsolyának, Barna Máténak, Győrffy Villőnek, Győri Tamásnak, Kiss Noéminek, Lengyel Alexandrának, Nagy Ildikónak, Nedreu Angelikának, Polgár Juditnak, Szatmári Zsoltnak és VargaUrbán Erikának - az adatfelvételben nyújtott közremúködést. 


\section{Irodalom}

[1] Townsend N, Wilson L, Bhatnagar P, et al. Cardiovascular disease in Europe: epidemiological update 2016. Eur Heart J. 2016; 37: 3232-3245.

[2] Nichols M, Townsend N, Sharborough P, et al. European Cardiovascular Disease Statistics September, 2012. European Heart Network, Brussels and European Society of Cardiology, Sophia Antipolis. Available from: http://www.ehnheart.org/cvd-statistics.html [accessed: July 2, 2019].

[3] Hungarian Central Statistical Office. (a) Angol cím (1990-). [Központi Statisztikai Hivatal. Népesség-népmozgalom (1990-).] Available from: https://www.ksh.hu/docs/hun/xstadat/xstadat_hosszu/h_wdsd001c.html [accessed: July 2, 2019]. [Hun garian]

[4] Hungarian Central Statistical Office. (b) Angol cím. (1990-) [Központi Statisztikai Hivatal. Halálozások a gyakoribb halálokok szerint (1990-).] Avaible from: https://www.ksh.hu/ docs/hun/xstadat/xstadat_eves/i_wnh001.html [accessed: July 2, 2019]. [Hungarian]

[5] Ginter E, Simko V. Dramatic decline of ischemic heart disease mortality in post communist Central Europe: recovery from totality. Cent Eur J Public Health 2012; 20: 101-103.

[6] Eurostat. Causes of death - standardised death rate 2015. Luxembourg. Avaible from: https://ec.europa.eu/eurostat/statistics-explained $/$ index.php? title=File: Causes_of_death_ \%E2\%80\%94_standardised_death_rate,_2015_(per_100_000_ inhabitants_aged_less_than_65)_HLTH18.png [accessed: July 2, 2019].

[7] Bagyura Z, Kiss L, Édes E, et al. Cardiovascular screening programme in the Central Hungarian region. The Budakalasz study. [Cardiovascularis szűrőprogram a közép-magyarországi régióban. Budakalász Vizsgálat.] Orv Hetil. 2014; 155: 1344 1352. [Hungarian]

[8] Strike PC, Steptoe A. Psychosocial factors in the development of coronary artery disease. Prog Cardiovasc Dis. 2004; 46: $337-$ 347.

[9] Berry JD, Lloyd-Jones DM, Garside DB, et al. Social avoidance and long-term risk for cardiovascular disease death in healthy men: the Western Electric Study. Ann Epidemiol. 2007; 17: 591-596

[10] Cohen S. Social relationships and health. Am Psychol. 2004; 59: 676-684.

[11] Lett HS, Blumenthal JA, Babyak MA, et al. Social support and coronary heart disease: epidemiologic evidence and implications for treatment. Psychosom Med. 2005; 67: 869-878.

[12] Uchino BN. Social support and health: a review of physiological processes potentially underlying links to disease outcomes. J Behav Med. 2006; 29: 377-387.

[13] Taylor SE. Social support. In: Friedman HS, Silver RC. (eds.) Foundations of health psychology. Oxford University Press, New York, NY, 2007; pp. 145-171.

[14] Cobb S. Social support as a moderator of life stress. Psychosom Med. 1976; 38: 300-314.

[15] Heffner KL, Waring ME, Roberts MB, et al. Social isolation, Creactive protein, and coronary heart disease mortality among community-dwelling adults. Soc Sci Med. 2011; 72: 1482-1488.

[16] Tay L, Tan K, Diener E, et al. Social relations, health and health outcomes: a survey and synthesis. Appl Psychol Health Well Being 2013; 5: 28-78

[17] Holt-Lunstad, J, Smith TB, Layton JB. Social relationships and mortality risk: a meta-analytic review. PLoS Med. 2010; 7: e1000316.

[18] Creaven AM, Howard S, Hughes BM. Social support and trait personality are independently associated with resting cardiovascular function in women. Br J Health Psychol. 2013; 18: 556573.
[19] Seeman TE, Gruenewald TL, Cohen S, et al. Social relationships and their biological correlates: Coronary Artery Risk Development in Young Adults (CARDIA) study. Psychoneuroendocrinology 2014; 43: 126-138.

[20] Yang YC, Schorpp K, Harris KM. Social support, social strain and inflammation: evidence from a national longitudinal study of US adults. Soc Sci Med. 2014; 107: 124-135.

[21] Steptoe A, Kivimäki M. Stress and cardiovascular disease: an update on current knowledge. Annu Rev Public Health 2013; 34: 337-354.

[22] Everson-Rose SA, Lewis TT. Psychosocial factors and cardiovascular diseases. Annu Rev Public Health 2005; 26: 469-500.

[23] Norekvål TM, Fridlund B, Rokne B, et al. Patient-reported outcomes as predictors of 10-year survival in women after acute myocardial infarction. Health Qual Life Outcomes 2010; 8: 140.

[24] Kamiya, Y, Whelan B, Timonen V, et al. The differential impact of subjective and objective aspects of social engagement on cardiovascular risk factors. BMC Geriatr. 2010; 10: 81 .

[25] Steptoe A, Shankar A, Demakakos P, et al. Social isolation, loneliness, and all-cause mortality in older men and women. Proc Natl Acad Sci U S A 2013; 110: 5797-5801.

[26] Rutledge T, Linke SE, Olson MB, et al. Social networks and incident stroke among women with suspected myocardial ischemia. Psychosom Med. 2008; 70: 282-287.

[27] Ramsay S, Ebrahim S, Whincup P, et al. Social engagement and the risk of cardiovascular disease mortality: results of a prospective population-based study of older men. Ann Epidemiol. 2008; 18: $476-483$

[28] Rosengren A, Wilhelmsen L, Orth-Gomér K. Coronary disease in relation to social support and social class in Swedish men. A 15 year follow-up in the study of men born in 1933. Eur Heart J. 2004; 25 : 56-63.

[29] Zimet G, Dahlem NW, Zimet SG, et al. The multidimensional scale of social support. J Pers Assess. 1988; 52: 30-41.

[30] Zimet GD, Powell SS, Farley GK, et al. Psychometric characteristics of the Multidimensional Scale of Perceived Social Support. J Pers Assess. 1990; 55: 610-617.

[31] Canty-Mitchell, J, Zimet GD. Psychometric properties of the Multidimensional Scale of Perceived Social Support in urban adolescents. Am J Community Psychol. 2000; 28: 391-400.

[32] Papp-Zipernovszky O, Kékesi MZ, Jámbori Sz. Validation of the Hungarian version of Multidimensional Scale of Perceived Social Support. [A Multidimenzionális Észlelt Társas Támogatás kérdőív magyar nyelvű validálása.] Mentálhig Pszichoszomat. 2017; 18: 230-262. [Hungarian]

[33] Beck AT, Beck RW. Screening depressed patients in family practice. A rapid technic. Postgrad Med. 1972; 52: 81-85.

[34] Rózsa S, Szádóczky E, Füredi J. Psychometric characteristics of Short form of Beck Depression Inventory in Hungarian sample. [A Beck Depresszió Kérdőív rövidített változatának jellemzői hazai mintán.] Psychiat Hung. 2001; 16: 384-402. [Hungarian]

[35] Susánszky É, Konkolÿ TB, Stauder A, et al. Validation of the short (5-item) version of the WHO Well-BBeing Scale based on a Hungarian representative health survey (Hungarostudy 2002). [A WHO Jól-lét Kérdőív rövidített (WBI-5) magyar változatának validálása a Hungarostudy 2002 országos lakossági egészségfelmérés alapján.] Mentálhig Pszichoszomat. 2006; 7: 247-255. [Hungarian]

[36] Stauder A, Konkoly TB. Characteristics of the Hungarian version of Perceived Stress Scale (PSS). [Az észlelt stressz kérdő́iv (PSS) magyar verziójának jellemzői.] Mentálhig Pszichoszomat. 2006; 7: 203-216. [Hungarian]

[37] Fischer Aggarwal BA, Liao M, Mosca L. Physical activity as a potential mechanism through which social support may reduce cardiovascular disease risk. J Cardiovasc Nurs. 2008; 23: 90-96.

[38] Piwoński J, Piwońska A, Sygnowska E. Is level of social support associated with health behaviours modifying cardiovascular risk? Results of the WOBASZ study. Kardiol Pol. 2012; 70: 803-809. 
[39] Gariépy G, Honkaniemi H, Quesnel-Vallée A. Social support and protection from depression: systematic review of current findings in Western countries. Br J Psychiatry 2016; 209: 284-293.

[40] Frasure-Smith N, Lespérance F, Gravel G, et al. Social support, depression, and mortality during the first year after myocardial infarction. Circulation 2000; 101: 1919-1924.

[41] Peirce RS, Frone MR, Russell M, et al. A longitudinal model of social contact, social support, depression, and alcohol use. Health Psychol. 2000; 19: 28-38.

[42] Gafarov VV, Panov DO, Gromova EA, et al. The influence of social support on risk of acute cardiovascular disease in female population aged 25-64 in Russia. Int J Circumpolar Health 2013; 72: 10.3402/ijch.v72i0.21210.
[43] Compare A, Zarbo C, Manzoni GM, et al. Social support, depression, and heart disease: a ten year literature review. Front Psychol. 2013; 4: 384

[44] Grav S, Hellzèn O, Romild U, et al. Association between social support and depression in the general population: the HUNT study, a cross-sectional survey. J Clin Nurs. 2011; 21: 111-120.

(Ocsovszky Zsófia, Budapest, Városmajor u. 68., 1122 e-mail: ocsovszky.zsofia@med.semmelweis-univ.hu)

\section{Felhívás és értesítő}

magyar egészségügyi dolgozók (orvos, fogorvos, gyógyszerész, tudományos kutató, ápoló, asszisztens, gyógytornász, egyéb szakdolgozó, szociális munkás, stb.) részére

\section{Nemzetközi orvos-képzőművész kiállítássorozat \\ 2020. május 9. - Bécs \\ Jelentkezési határidő: 2020. január 31.}

További információ és komplett jelentkezési anyag a palotas@asklepios-med.eu e-mail címen kérhető.

Bármilyen képzőművészeti alkotás (festmény, szobor, kisplasztika, ékszerek, míves használati tárgyak, fotó, stb.) bemutatható. Semmiféle „szelekció” vagy „cenzúra” nincs.

A rendezvény non-profit módon kerül megrendezésre: teljesen térítésmentes a részvétel, mind a művek kiállitása, mind pedig a közönség soraiban történő megjelenés mindenki számára ingyenes.

A világ minden tájáról várunk müvész kollégákat, így lehetőség nyilik hazai és külföldi orvosokkal, egészségügyi dolgozókkal szakmai, valamint kulturális kapcsolat felvételére is.

Együttműködésüket, valamint a rendezvényen való részvételüket elöre is köszönöm.

Üdvözlettel:

Prof. Dr. Palotás András

alapító és vezető

Asklepios-Med (www.asklepios-med.eu)

Telefon: +36 (30) 255-6225

E-mail: palotas@asklepios-med.eu

H-6722 Szeged, Kossuth Lajos sgt. 23.

A cikk a Creative Commons Attribution 4.0 International License (https://creativecommons.org/licenses/by/4.0/) feltételei szerint publikált Open Access közlemény, melynek szellemében a cikk bármilyen médiumban szabadon felhasználható, megosztható és újraközölhetö, feltéve, hogy az eredeti szerző és a közlés helye, illetve a CC License linkje és az esetlegesen végrehajtott módositások feltüntetésre kerülnek. (SID_1) 